\title{
Insiden dan Mortalitas Penderita Kanker Serviks di RSUP Prof. Dr. R. D. Kandou Periode Januari 2014 - September 2015
}

\author{
${ }^{1}$ Frits S. Mamesah \\ ${ }^{2}$ Bismarck J. Laihad \\ ${ }^{2}$ Juneke J. Kaeng
}

\author{
${ }^{1}$ Program Studi Pendidikan Dokter Fakultas Kedokteran Universitas Sam Ratulangi Manado \\ ${ }^{2}$ Bagian/SMF Obstetri dan Ginekologi Fakultas Kedokteran Universitas Sam Ratulangi \\ RSUP Prof. Dr. R. D. Kandou Manado \\ Email: frits_mamesah@yahoo.com
}

\begin{abstract}
Cervical cancer is caused by human papiloma virus (HPV). It is a malignant disease in obstetrics and gynecology field which still occupies the highest position cancer among females woman. This study was aimed to obtain the incidence and mortality of cervical cancer patients at Prof. Dr. R. D. Kandou Hospital Manado from january 2014- september 2015. This was a descriptivease retrospective study using patients' medical record data of cervical cancer. The results showed that there were 121 patients of cervical cancer, most were in the age group of 41-50 years (39.67\%) and stage III B (41 people; 33.89\%); 23 patients $(19.00 \%)$ died. Conclusion: The incidence of cervical cancer at Prof. Dr. R. D. Kandou Hospital Manado was high enough with a mortality rate of $19.00 \%$.
\end{abstract}

Keywords: cervical cancer

\begin{abstract}
Abstrak: Kanker serviks disebabkan oleh Human Papiloma Virus (HPV) dan merupakan salah satu penyakit keganasan di bidang obstetrik dan ginekologi yang masih menempati posisi tertinggi sebagai penyakit kanker yang menyerang kaum perempuan. Penelitian ini bertujuan untuk mengetahui insiden dan mortalitas pasien kanker serviks di RSUP Prof. Dr. R. D. Kandou Manado sejak Januari 2014-Septemper 2015. Jenis penelitian ialah deskriptif retrospektif dengan menggunakan data rekam medik pasien kanker serviks. Hasil penelitian mendapatkan 121 kasus kanker serviks, terbanyak pada kelompok usia 41-50 tahun (39,67\%). Kebanyakan pasien berada pada stadium IIIB sebanyak 41 orang $(33,89 \%)$ dan 23 penderita $(19,00 \%)$ dinyatakan meninggal dunia. Simpulan: Insiden penderita kanker serviks di RSUP Prof. Dr. R. D. Kandou Manado cukup tinggi dengan angka mortalitas sebesar 19,00\%.
\end{abstract}

Kata kunci: kanker serviks

Untuk mewujudkan tujuan pembangunan Indonesia sehat 2010 perlu didukung dengan kondisi masyarakat Indonesia yang sehat. Sehat dalam hal ini, perlu dirasakan oleh semua kalangan masyarakat tidak terkecuali bagi kaum perempuan. Masalah kesehatan yang dialami oleh perempuan sangat beragam; salah satunya ialah kanker serviks. ${ }^{1}$

Kanker serviks disebabkan oleh virus human papilloma virus (HPV). Penularan virus HPV dapat terjadi dari seorang penderita kepada orang lain dan menginfeksi orang tersebut. Gejala yang mungkin timbul (umumnya pada stadium lanjut) ialah perdarahan diluar masa haid, jumlah darah haid yang tidak normal, perdarahan pada masa menepouse (setelah berhenti haid), keputihan yang bercampur darah atau nanah yang berbau, perdarahan sesudah sanggama, rasa nyeri dan sakit dipanggul, gangguan buang air kecil 
sampai tidak bisa buang air kecil. ${ }^{2}$

Berdasarkan hasil survei kesehatan oleh World Health Organitation (WHO) 2010, dilaporkan kejadian kanker serviks sebesar 500.000 kasus baru di dunia. Hal ini dapat dirata-ratakan bahwa setiap 2 menit ada perempuan yang menjadi korban dari penyakit yang berbahaya ini. Kejadian kanker serviks di Indonesia diperkirakan setiap harinya ada 40-45 kasus baru yang dapat ditemukan setiap hari. Hal ini menunjukkan bahwa tingkat insiden dari kasus kanker serviks di Indonesia berpotensi meningkat dari waktu ke waktu. ${ }^{3}$

Bukan hanya tingkat insiden yang perlu diberi perhatian tapi juga tingginya angka mortalitas upaya pencegahan dan eas sebagai akibat dari penyakit kanker serviks. Angka mortalitas dipengaruhi oleh minimnya pengetahuan perempuan mengenai kanker serviks serta upaya pencegahan dan pengobatannya sehingga kebanyakan penderita kanker serviks justru datang ke rumah sakit dalam kondisi yang sudah memasuki stadium lanjut. ${ }^{4}$

Tingkat insiden penyakit kanker serviks perlu diperhatikan dan dicari solusi agar angka mortalitas dapat diperkecil. ${ }^{5} \mathrm{Di}$ RSUP Prof. Dr. R. D. Kandou Manado, sering ditemukan kasus tersebut. Penderita kanker serviks datang untuk memeriksakan diri saat kondisinya sudah berlanjut ke stadium akhir.

Penelitian ini bertujuan untuk mendapatkan insiden dan angka mortalitas penderita kanker serviks yang berkunjung di RSUP Prof. Dr. R. D. Kandou Manado dalam kurun waktu Januari 2014 September 2015.

\section{METODE PENELITIAN}

Jenis penelitian ini ialah deskriptif retrospektif menggunakan data rekam medik pasien. Penelitian ini dilakukan di Bagian Obstetri dan Ginekologi RSUP Prof. Dr. R. D. Kandou Manado pada bulan November - Desember 2015. Sampel penelitian diperoleh dari Bagian Rekam Medik dari pasien yang berkunjung ke Bagian Obstetrik dan Ginekologi RSUP Prof. R. D. Kandou Manado sejak Januari 2014-
Septemper 2015 yang berada pada rentang usia 25-50 tahun.

\section{HASIL PENELITIAN}

Hasil penelitian mendapatkan 121 kasus dengan kanker serviks sejak Januari 2014-Septemper 2015. Tabel 1 menunjukkan bahwa usia 41-50 tahun merupakan kelompok usia dengan jumlah sampel terbanyak yakni 48 orang $(39,67 \%)$ sedangkan yang paling sedikit pada kelompok usia 71-80 tahun sebanyak 2 orang $(1,65 \%)$.

Tabel 1. Distribusi frekuensi menurut usia

\begin{tabular}{ccc}
\hline Usia & $\mathbf{n}$ & \% \\
\hline $20-30$ & 3 & 2,47 \\
$31-40$ & 17 & 14,05 \\
$41-50$ & 48 & 39,67 \\
$51-60$ & 37 & 30,58 \\
$61-70$ & 14 & 11,58 \\
$71-80$ & 2 & 1,65 \\
Total & 121 & 100 \\
\hline
\end{tabular}

Tabel 2 menunjukkan bahwa berdasarkan jumlah paritas, jumlah sampel terbesar ialah dengan jumlah paritas 1-2 kali yakni sebanyak 57 orang $(57,47 \%)$, dan yang paling kecil ialah sampel dengan jumlah paritas 0 yakni 1 orang $(0,82 \%)$.

Tabel 2. Distribusi frekuensi responden berdasarkan jumlah paritas

\begin{tabular}{ccc}
\hline Jumlah paritas & $\mathbf{n}$ & $\mathbf{\%}$ \\
\hline 0 & 1 & 0,82 \\
$1-2$ & 57 & 57,47 \\
$3-4$ & 48 & 39,67 \\
$5-6$ & 12 & 9,92 \\
$7-8$ & 3 & 2,48 \\
Total & 121 & 100 \\
\hline
\end{tabular}

Tabel 3 menunjukkan bahwa tingkat pendidikan sampel terbanyak dengan tingkat pendidikan terakhir SLTA sebanyak 79 orang $(65,29 \%)$; tidak ada sampel yang tidak bersekolah.

Tabel 4 memperlihatkan bahwa stadium kanker serviks terbanyak ialah stadium IIIB yaitu 41 orang $(33,89 \%)$. 
Tabel 3. Distribusi frekuensi sampel berdasarkan tingkat pendidikan

\begin{tabular}{ccc}
\hline Tingkat pendidikan & $\mathbf{n}$ & $\mathbf{\%}$ \\
\hline Tidak sekolah & 0 & 0 \\
SD & 19 & 15,71 \\
SLTP & 16 & 13,23 \\
SLTA & 79 & 65,29 \\
Sarjana & 7 & 5,78 \\
Total & 121 & 100 \\
\hline
\end{tabular}

Tabel 4. Distribusi frekuensi sampel berdasarkan stadium kanker serviks

\begin{tabular}{ccc}
\hline Stadium & $\mathbf{n}$ & $\mathbf{\%}$ \\
\hline Residif & 4 & 3,30 \\
IA & 0 & 0 \\
IA1 & 0 & 0 \\
IA2 & 0 & 0 \\
IB & 3 & 2,48 \\
IB1 & 0 & 0 \\
IB2 & 7 & 5,78 \\
IIA & 20 & 16,53 \\
IIA1 & 0 & 0 \\
IIA2 & 8 & 6,62 \\
IIB & 14 & 11,57 \\
IIIA & 20 & 16,53 \\
IIIB & 41 & 33,89 \\
IVA & 2 & 1,65 \\
IVB & 2 & 1,65 \\
Total & 121 & 100 \\
\hline
\end{tabular}

Tabel 5 memperlihatkan bahwa proses pengobatan yang terbanyak dilakukan ialah non-operatif, yaitu 70 orang $(57,85 \%)$.

Tabel 5. Distribusi frekuensi sampel berdasarkan proses pengobatan yang dilakukan

\begin{tabular}{crc}
\hline Proses pengobatan & n & \% \\
\hline Operatif & 51 & 42,15 \\
Non-operatif & 70 & 57,85 \\
Total & 121 & 100 \\
\hline
\end{tabular}

Tabel 6 memperlihatkan bahwa dari 121 penderita kanker serviks terdapat 23 orang $(19,00 \%)$ yang meninggal.

Tabel 7 memperlihatkan bahwa pada penelitian ini, insiden tertinggi dari kanker serviks terdapat pada Juli-September 2014, yaitu $18,19 \%$.
Tabel 6. Jumlah penderita dan jumlah yang meninggal akibat kanker serviks diRSUP Prof. Dr. R. D. Kandou Manado

\begin{tabular}{ccc}
\hline $\begin{array}{c}\text { Jumlah penderita dan } \\
\text { jumlah yang meninggal }\end{array}$ & n & $\%$ \\
\hline Jumlah penderita & 121 & 100 \\
Jumlah yang meninggal & 23 & 19,00 \\
\hline
\end{tabular}

Tabel 7. Distribusi frekuensi sampel berdasarkan besarnya insiden sejak Januari 2014September 2015

\begin{tabular}{lcc}
\hline \multicolumn{1}{c}{ Bulan/Tahun } & N & \% \\
\hline Januari- Maret 2014 & 13 & 10,47 \\
April- Juni 2014 & 16 & 13,23 \\
Juli- September 2014 & 22 & 18,19 \\
Oktober- Desember 2014 & 15 & 12,40 \\
Januari- Maret 2015 & 19 & 15,70 \\
April- Juni 2015 & 17 & 14,04 \\
Juli- September 2015 & 19 & 15,70 \\
Total & 121 & 100 \\
\hline
\end{tabular}

\section{BAHASAN}

Usia dan juga tingkat pendidikan seseorang sangat memengaruhi pola hidup dari orang itu sendiri, termasuk kesehatannya. Usia yang telah lebih dewasa umumnya lebih memerhatikan kesehatannya dari pada yang lebih muda. Hal ini mungkin disebabkan karena individu yang lebih dewasa sudah mulai merasakan dampak dari penyakitnya yang bisa jadi sudah cukup lama dia derita. Begitu juga dengan pengaruh perubahan mukosa pada perempuan dimana setelah melewati proses paritas lebih rentan dengan penyakit ini dibandingkan dengan yang belum pernah paritas. $^{5}$

Tingkat pendidikan seseorang juga turut berpengaruh pada kesehatannya. Seseorang dengan pendidikan yang tinggi umumnya memiliki pengetahuan tentang pentingnya merawat kesehatan dan caracara menghindari penyakit.

Kanker serviks adalah tumor ganas primer yang berasal dari metaplasia epitel di daerah squamocolumnar junction yaitu daerah peralihan mukosa vagina dan mukosa kanalis servikalis. ${ }^{6}$ Kanker serviks biasanya menyerang perempuan berusia 33-55 tahun. Sebanyak 90\% dari kanker 
leher rahim berasal dari sel skuamos yang melapisi serviks dan $10 \%$ sisanya berasal dari sel kelenjar penghasil lendir pada saluran servikal yang menuju ke rahim.

Di Indonesia, insiden kanker serviks diperkirakan kurang lebih 40.000 kasus pertahun dan masih merupakan kanker pada perempuan yang paling sering terjadi. Di RSUP Prof. Dr. R. D. Kandou Manado selang bulan Januari 2014-September 2015 terdapat 121 kasus. Tingginya frekuensi ini perlu mendapat perhatian dari pemerintah dan instansi terkait. Hal ini bisa saja karena kurangnya tingkat pengetahuan masyarakat terhadap bahaya dari kanker serviks.

Penderita kanker serviks datang ke rumah sakit dengan beberapa stadium; yang terbanyak ialah stadium IIIB. Pada stadium ini umumnya pasien sudah mulai merasakan berbagai keluhan seperti rasa nyeri pada panggul yang disebabkan karena tumor telah meluas ke dinding pelvis sehingga menyebabkan hidronefrosis atau ginjal yang tidak berfungsi. Hal ini bisa dihindari bila saja masyarakat pada umumnya dan perempuan khususnya paham betul dengan kanker serviks. Kebanaykan penderita meskipun sudah mulai merasakan keluhan-keluhan di daerah rahim atau perutnya cenderung tidak langsung memeriksakan diri, yang mungkin disebabkan oleh kurangnya pengetahuan, kesibukan, dan faktor ekonomi.

Terapi atau pengobatan kanker serviks dilakukan bilamana diagnosis telah dipastikan secara histologik. Pemilihan pengobatan kanker serviks tergantung pada lokasi dan ukuran tumor, stadium penyakit, usia, keadaan umum penderita, dan juga rencana penderita tentang kehamilan selanjutnya. Lesi tingkat rendah biasanya tidak memerlukan pengobatan lebih lanjut, terutama jika daerah yang abnormal seluruhnya telah diangkat pada waktu pemeriksaan biopsi. Pengobatan pada lesi prekanker bisa berupa kriosurgeri (pembekuan), kauterisasi (pembakaran atau diatermi), pembedahan laser untuk menghancurkan sel-sel yang abnormal tanpa melukai jaringan yang sehat di sekitarnya, dan loop electrosurgical procedure (LEEP) atau konisasi. ${ }^{7}$
Proses pengobatan yang ditempuh pada penelitian ini terbanyak ialah proses non-operatif dimana pasien diberikan obatobatan untuk pencegahan penyakit bertambah parah atau perawatan sehingga kondisi keadaaan umum bisa lebih baik. Hal ini bisa dilakukan karena memang belum diperlukan tindakan operatif atau juga karena pasien sendiri yang enggan menjalani tindakan operatif terhadap dirinya. Ada juga pasien yang pada proses pengobatannya dilakukan proses operatif seperti transfusi, biopsi, dan kemoterapi. Selain karena memang tindakan operatif sudah diperlukan, bisa juga karena pasien menginginkannya.

Insiden kanker serviks di RSUP Prof. Dr. R. D. Kandou Manado selama kurun waktu satu tahun lebih yakni sejak Januari 2014-September 2015 ialah sebanyak 121 kasus. Mortalitas penderita kanker serviks di RSUP Prof. Dr. R. D. Kandou Manado sebanyak 23 orang. Angka mortalitas sendiri cukup tinggi karena tingginya stadium penyakit kanker serviks dari penderita tersebut. Hanya saja kebanyakan penderita datang justru saat penyakit telah memasuki stadium III dan IV. Hal ini sebetulnya bisa dihindari melalui upaya-upaya yang bisa dilakukan oleh pemerintah yang kemudian dapat bekerjasama dengan instansi-instansi kesehatan lewat penyuluhan atau cara lainnya untuk lebih memperkenalkan apa dan bagaimana kanker serviks itu.

\section{SIMPULAN}

Berdasarkan hasil penelitian ini dapat disimpulkan bahwa insiden penderita kanker serviks di RSUP Prof. Dr. R. D. Kandou Manado periode Januari 2014September 2015 cukup tinggi dengan angka mortalitas sebesar $19,00 \%$.

\section{SARAN}

Disarankan kepada pemerintah Kecamatan melalui Dinas Kesehatan, agar dapat melakukan berbagai penyuluhan dan sosialisasi guna menambah informasi kepada masyarakat khususnya kaum perempuan tentang kanker serviks termasuk cici-ciri dan penanganannya. 
Disarankan kepada masyarakat khususnya kaum perempuan untuk lebih aktif dalam mencari informasi mengenai kanker serviks sehingga mereka tidak hanya sekedar tahu tetapi juga dapat mengaplikasikan hasil tahu dalam bentuk sikap dan tindakan dalam kehidupan sehari-hari sebagai bagian dari peningkatan derajat kesehatan.

\section{DAFTAR PUSTAKA}

1. Depkes RI. Profil Kesehatan Indonesia. Jakarta, 2010

2. Prawirohardjo S. Acuan Nasional Pelayanan Kesehatan Maternal dan Neonatal. Jakarta: Yayasan Bina Pustaka Sarwono Prawirohardjo, 2005.

3. The Global Health Observatory (GHO) is WHO's portal providing access to data and analysis for monitoring the global health situation. [serial online] 2013. [cited 2015 Oct 12]. Available from:http://www $>$ who>int/gho,

4. Britannian 2007. Sistem Reproduksi Wanita. Encyclopedia Britannica. [cited 2015 Oct 12]. Available from: http://www. britannian.com/EBchecked/media/4817 9/sistem-organ-reproduksiwanita.

5. Saifuddin AB. Buku Acuan Nasional Pelayanan Kesehatan Maternal dan Neonatal. Jakarta: Yayasan Bina Pustaka, 2006.

6. Hacker NFJ, George M. Essensial Obstetri dan Ginekologi (2nd ed). Nugrohu E, alih bahasa. Jakarta: Hipokrates, 2004.

7. Oxcorn H. Ilmu Kebidanan. Fisiologi dan Patologi Persalinan. Jakarta: Yayasan Essentia Medica, 2003. 